ISSN: $1410-8917$

Jurnal Kimia

- Sains \&

Aplikasi
Jurnal Kimia Sains dan Aplikasi Journal of Scientific and Applied Chemistry

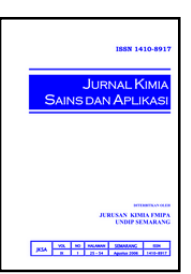

\title{
Isolasi Enzim L-Asparaginase dari Rimpang Temulawak (Curcuma xanthorrhiza Roxb.) dan Uji Potensi terhadap Kultur Sel Leukemia Tipe K562
}

\author{
Oktarina Puspitasari ${ }^{\mathrm{a}}$, Wuryanti ${ }^{\mathrm{a}^{*}}$ \\ a Biochemistry Laboratory, Chemistry Department, Faculty of Sciences and Mathematics, Diponegoro University, Jalan Prof. \\ Soedarto, Tembalang, Semarang 50275 \\ * Corresponding author: wuryanti@live.undip.ac.id
}

\section{Article Info}

Keywords:

L-Asparaginase, anticancer, temulawak, MTT, ELISA Reader)

\section{Abstract}

Enzyme L-Asparaginase is an enzyme that hydrolyzes L-asparagin to L-aspartic acid and ammonia. L-Asparaginase can be used to treat cancer, which works by inhibiting protein synthesis of cancer cells without damaging normal cells. One of the L-Asparaginase source plants is temulawak (Curcuma xanthorrhiza Roxb.). The objectives of this study were to isolate L-Asparaginase from temulawak rhizome, to determine the initial enzyme activity of LAsparaginase, and to find potency of L-Asparaginase enzyme anticancer effect against K562 leukemia cell. Isolation and testing of L-Asparaginase enzyme potential from temulawak rhizomes were conducted in several stages. The first stage was the insulation and partial purification of L-Asparaginase enzyme from the temulawak rhizome. The second stage was a activity specific test of $\mathrm{L}$-Asparaginase enzyme at optimum condition $\left(37^{\circ} \mathrm{C}, \mathrm{pH} 8,6\right.$, and incubation time $30 \mathrm{~min}$ ). In the enzyme with the highest specific activity, an anticancer test was performed on cell leukaemia type K562 with cell viability method with addition of MTT and measurement using ELISA Reader. L-Asparaginase enzyme from Temulawak rhizome had specific activity of 77.18 unit/mg protein at fraction 4 (fraction with $60-80 \%$ saturation level). However, fraction 4 was less potential for leukaemia cell anticancer activity type $\mathrm{K} 562$ as obtained $\mathrm{LC}_{50}$ of $534.89 \mathrm{\mu g} / \mathrm{mL}$, while the standard of a bioactive compound as anticancer has $\mathrm{LC}_{50}$ of $20 \mu \mathrm{g} / \mathrm{mL}$.

\section{Abstrak}

Enzim L-Asparaginase merupakan enzim yang menghidrolisis L-asparagin menjadi asam Laspartat dan amonia. L-Asparaginase dapat digunakan untuk mengobati penyakit kanker, yang bekerja dengan cara menghambat sintesis protein sel kanker tanpa merusak sel normal. Salah satu tumbuhan sumber L-Asparaginase adalah temulawak (Curcuma xanthorrhiza Roxb.). Tujuan penelitian ini yaitu mengisolasi L-Asparaginase dari rimpang temulawak, menentukan nilai aktivitas spesifik enzim L-Asparaginase hasil isolasi, dan mengetahui potensi antikanker enzim L-Asparaginase hasil isolasi terhadap sel leukemia tipe K562. Isolasi dan uji potensi enzim L-Asparaginase dari rimpang temulawak dilakukan beberapa tahap. Tahap pertama yaitu isolasi dan pemurnian parsial enzim L-Asparaginase dari rimpang temulawak. Tahap kedua yaitu uji aktivitas spesifik enzim L-Asparaginase pada kondisi optimum (suhu $37^{\circ} \mathrm{C}, \mathrm{pH}$ 8,6 , dan waktu inkubasi 30 menit). Pada enzim dengan aktivitas spesifik tertinggi dilakukan uji antikanker terhadap sel leukemia tipe K562 dengan metode viabilitas sel dengan penambahan MTT dan pengukuran menggunakan ELISA Reader. Enzim L-Asparaginase dari rimpang temulawak mempunyai aktivitas spesifik sebesar 77,18 unit/mg protein pada fraksi 4 (fraksi dengan tingkat kejenuhan 60-80\%). Namun fraksi 4 tersebut kurang potensial untuk aktivitas antikanker sel leukemia tipe $\mathrm{K} 562$ karena diperoleh $\mathrm{LC}_{50}$ sebesar 534,89 $\mathrm{\mu g} / \mathrm{mL}$, sedangkan standart suatu senyawa bioaktif sebagai antikanker adalah $\mathrm{LC}_{50} \leq 20 \mathrm{\mu g} / \mathrm{mL}$. 


\section{Pendahuluan}

Kanker merupakan salah satu penyakit yang ditandai dengan pembelahan sel yang tidak terkendali dan kemampuan sel-sel tersebut untuk menyerang jaringan biologis lainnya, baik dengan pertumbuhan langsung di jaringan yang bersebelahan (invasi) atau dengan migrasi sel ke tempat yang jauh (metastasis). Kanker merupakan penyakit yang menempati peringkat kedua di dunia sebagai penyebab kematian. Berbagai usaha dilakukan untuk menyembuhkan penyakit kanker. Salah satu usaha yang sedang intensif dilakukan adalah melalui pencarian senyawa antikanker dari bahan alam. Umumnya pengobatan kanker dilakukan dengan obat-obat sintesis dan radiasi terapi yang digunakan tersebut banyak menimbulkan efek samping yang merugikan penderita [1]. Hal ini menyebabkan penelitian untuk menemukan obat-obat baru terus berkembang, salah satu cara yang dilakukan adalah dengan mengembangkan pengobatan dari bahan alam [2].

Enzim adalah molekul protein yang sangat besar yang dapat digunakan sebagai katalis organik yang mempercepat reaksi biologis berjuta-juta kali [3]. Sekarang ini penggunaan enzim telah semakin luas yaitu di bidang pangan dan kesehatan. Salah satu enzim yang sangat berperan di dalam bidang kesehatan yaitu L-Asparaginase.

L-Asparaginase adalah enzim yang mengkatalisis reaksi hidrolisis L-asparagin menjadi L-aspartat dan amonia [4]. L-asparagin merupakan asam amino nonesensial [5] yang dibutuhkan oleh sel untuk sintesis protein dan pertumbuhan. Pada sel penderita leukemia limfoblastik akut, jumlah asparagin sintetase terbatas, sehingga ketersediaan asparagin bergantung dari luar sel [6], sedangkan pada sel normal asparagin sintetase dapat bekerja secara normal menghasilkan asparagin [5]. Adanya L-Asparaginase dalam tubuh akan mengakibatkan penurunan konsentrasi asparagin dalam darah sehingga asupan asparagin bagi sel kanker tersebut menjadi sangat terbatas dan sintesis protein pada sel tersebut akan terganggu yang pada akhirnya akan menghambat pertumbuhan sel kanker, dan mengakibatkan kematian sel kanker tersebut. Selain itu aktivitas L-Asparaginase tidak mengganggu sel normal, karena sel normal mampu menghasilkan enzim asparagin sintetase dalam jumlah yang semestinya, sehingga kebutuhan asparagin akan dapat dipenuhi oleh sel normal itu sendiri [5].

Indonesia merupakan negara tropis yang memiliki keanekaragaman hayati, sehingga berpotensi besar dalam memperoleh L-Asparaginase dari tumbuhan. Berdasarkan penelitian sebelumnya, salah satu tumbuhan yang dapat digunakan sebagai sumber LAsparaginase adalah temulawak. Enzim L-Asparaginase pada fraksi ke-4 dari rimpang temulawak mempunyai aktifitas spesifik yang besar dibanding dengan fraksifraksi yang lain dalam rimpang temulawak, sehingga diharapkan memiliki potensi sebagai antikanker [7]. Oleh karena itu perlu dilakukan penelitian lebih lanjut untuk mengetahui potensi enzim L-Asparaginase dari rimpang temulawak terhadap sel kanker.

\section{Metodologi Penelitian}

\section{Alat dan bahan}

Alat-alat yang digunakan adalah sentrifugator (Centrific-228), inkubator (Memmert), blender (Philip), neraca analitik (Kern 870), pHmeter (Ezodo), magnetic stirer (Thermolyne Cimarec), alat-alat kultur sel, spektrofotometer UV-Vis (Shimadzu), laminar air flow, 96-well plate (Nunc), mikroskop fluoresen dan ELISA reader. Bahan-bahan yang digunakan adalah BSA (Bovine Serum Albumin), TCA (Trichloracetic acid), Bufer Tris-hidroksimetil-aminometan, Folin-ciocalteau, Kalium-natrium tartrat, L-asparagin (Merck), Amonium sulfat, Raksa (II) klorida, Asam klorida, Natrium karbonat, Kalium iodida, Barium (II) klorida, Natrium hidroksida, Tembaga (II) sulfat, temulawak (Curcuma xanthorrhiza Roxb), akuades, Sel Kanker leukemia tipe K562 yang dibiakkan oleh LPPT UGM, Larutan Bufer natrium fosfat $5 \mathrm{mM} \mathrm{pH} \mathrm{7,2} \mathrm{yang} \mathrm{mengandung} 0,14 \mathrm{M}$ $\mathrm{NaCl}$, IMDM 1640 (Iscove's Modified Dulbecco's Media) (Sigma), FBS (Fetal Bovine Serum) 10\% (v/v) (Gibco), RPMI (sigma), larutan MTT ( [3-(4,5-Dimethylthiazol2 yl)-2,5-diphenyltetrazolium bromida] ) dan kertas saring yang semuanya berkualitas p.a, kecuali temulawak, akuades dan kertas saring.

\section{Isolasi Enzim}

Serbuk temulawak (Curcuma xanthorrhiza Roxb) sebanyak $1000 \mathrm{~g}$ ditambahkan $500 \mathrm{~mL}$ bufer Trishidroksimetil-aminometan $0,2 \mathrm{M} \mathrm{pH}=8,6$ dan diblender selama 20 menit. Campuran kemudian dibiarkan selama 1,5 jam pada suhu $5^{\circ} \mathrm{C}$ lalu disaring. Filtrat kemudian disentrifugasi pada 3400 rpm selama 10 menit. Filtrat yang diperoleh dari sentrifugasi pada 3400 rpm disebut ekstrak kasar (EK).

\section{Fraksinasi Enzim}

Fraksinasi enzim dilakukan dengan menggunakan amonium sulfat secara bertingkat dengan tingkat kejenuhan $0-20 \%\left(\mathrm{~F}_{1}\right), 20-40 \%\left(\mathrm{~F}_{2}\right), 40-60 \%\left(\mathrm{~F}_{3}\right)$, $60-80 \%\left(\mathrm{~F}_{4}\right), 80-100 \%\left(\mathrm{~F}_{5}\right)$. Amonium sulfat ditimbang sesuai fraksi yang dikehendaki agar diperoleh konsentrasi yang diinginkan, lalu dimasukkan ke dalam filtrat hasil akhir tahap isolasi enzim sedikit demi sedikit sambil diaduk dengan magnetic stirer dalam penangas es. Campuran kemudian didiamkan selama 1 malam dalam keadaan dingin $\left(5^{\circ} \mathrm{C}\right)$, kemudian disentrifugasi dengan kecepatan $3500 \mathrm{rpm}$ selama 50 menit. Endapan yang diperoleh dipisahkan dari filtratnya dan disuspensi dengan $3 \mathrm{~mL}$ bufer Trishidroksimetil-aminometan $0,2 \mathrm{M} \mathrm{pH}=8,6$. Endapan yang disuspensi tersebut merupakan $\mathrm{EK}, \mathrm{F}_{1}, \mathrm{~F}_{2}, \mathrm{~F}_{3}, \mathrm{~F}_{4}, \mathrm{~F}_{5}$.

\section{Dialisis Enzim}

Dialisis dilakukan dengan menggunakan membran selofan yang telah direbus selama 30 menit dan dicuci dengan akuades. Selofan yang berisi suspensi hasil akhir fraksinasi enzim direndam dalam bufer Trishidroksimetil-aminometan $0,002 \mathrm{M} \mathrm{pH}=8,6$ dalam 
keadaan dingin dan tiap 2 jam bufer diganti serta diuji kandungan amonium sulfat pada larutan di luar selofan dengan $\mathrm{BaCl}_{2}$ 0,01 $\mathrm{M}$ hingga tidak terbentuk endapan putih.

\section{Penentuan Unit Aktivitas Enzim}

Disiapkan sebanyak 6 tabung dan masing-masing diisi dengan $1 \mathrm{~mL}$ larutan substrat $\mathrm{L}$-asparagin 0,1665 $\mathrm{M}, 0,1 \mathrm{~mL}$ endapan yang disuspensi $\left(\mathrm{EK}, \mathrm{F}_{1}, \mathrm{~F}_{2}, \mathrm{~F}_{3}, \mathrm{~F}_{4}\right.$, $\mathrm{F}_{5}$ ), dan 0,4 $\mathrm{mL}$ bufer Tris-hidroksimetil-aminometan $0,2 \mathrm{M} \mathrm{pH}=8,6$ dan diinkubasi pada suhu $37^{\circ} \mathrm{C}$ selama 30 menit, kemudian ditambah $1 \mathrm{~mL}$ larutan TCA 1,5 M dan disentrifugasi pada kecepatan $3400 \mathrm{rpm}$ selama 15 menit untuk memisahkan endapannya. Sebanyak 0,25 $\mathrm{mL}$ filtrat diambil lalu ditambah dengan 4,25 mL akuades dan 0,5 mL pereaksi Nessler, kemudian absorbansi larutan tersebut diukur dengan spektrofotometer UV-Vis pada panjang gelombang 420 $\mathrm{nm}$. Sebagai kontrol adalah 0,1 mL endapan yang disuspensi, yang telah dihilangkan aktifitasnya (dengan dipanaskan), ditambah $0,4 \mathrm{~mL}$ bufer Trishidroksimetil-aminometan 0,2 $\mathrm{M} \mathrm{pH}=8,6$ dan $0,5 \mathrm{~mL}$ larutan L-asparagin 0,1665 M. Aktivitas enzim ditentukan secara regresi linier terhadap kurva standar amonium sulfat.

\section{Penentuan Kadar Protein Enzim}

Sebanyak 0,1 $\mathrm{mL}$ larutan protein hasil fraksinasi (EK, $\mathrm{F}_{1}, \mathrm{~F}_{2}, \mathrm{~F}_{3}, \mathrm{~F}_{4}, \mathrm{~F}_{5}$ ) ditambah dengan $2 \mathrm{~mL}$ larutan Lowry $\mathrm{C}$, diinkubasi pada suhu optimum $\left(37^{\circ} \mathrm{C}\right)$ selama 30 menit sambil sesekali dikocok. Selanjutnya ditambah dengan 0,2 mL Lowry D dan diinkubasi selama 10 menit pada suhu kamar dengan sesekali dikocok, kemudian diukur absorbansinya. Absorbansi larutan diukur pada panjang gelombang $(\lambda)$ optimum BSA yaitu $720 \mathrm{~nm}$ dengan spektrofotometer UV-Vis. Kadar protein ditentukan secara regresi linier terhadap kurva standar BSA.

\section{Kultur Sel Kanker Darah (Leukemia)}

Sel leukemia yang telah siap dikultur dalam FBS dan IMDM, ketiganya diperoleh dari LPPT UGM Yogyakarta. Proses selanjutnya dikerjakan dengan teknik aseptik di bawah laminair air flow cabinet (LAFC).

\section{Proses Thawing Sel Leukemia}

Sel leukemia disentrifugasi dengan kecepatan 1500 rpm selama lima menit pada suhu $4^{\circ} \mathrm{C}$. Endapan sel ditanam pada botol kultur yang berisi media yang mengandung $10 \%$ FBS. Selanjutnya kultur disimpan dalam inkubator yang mengandung $95 \% \mathrm{CO}_{2}$ dan $5 \% \mathrm{O}_{2}$ pada suhu $37^{\circ} \mathrm{C}$ selama 24 jam.

\section{Inisiasi Kultur Sel Leukemia}

Disiapkan cawan petri steril bertutup. Homogenkan sel leukemia hasil thawing dan tuangkan ke masingmasing petri sebanyak $2 \mathrm{~mL}$. Inkubasi dalam inkubator yang mengandung $95 \% \mathrm{CO}_{2}$ dan $5 \% \mathrm{O}_{2}$ pada suhu $37^{\circ} \mathrm{C}$ selama $24 \mathrm{jam}$. Hitung jumlah sel/mL $\geq 104 \mathrm{sel} / \mathrm{mL}$ (Hidayat, 2002).

\section{Uji Sitotoksik Terhadap Sel Leukemia}

Larutan uji dibuat dengan seri dosis $1000 \mu \mathrm{g} / \mathrm{mL}$, $500 \mu \mathrm{g} / \mathrm{mL}, 250 \mu \mathrm{g} / \mathrm{mL}, 125 \mu \mathrm{g} / \mathrm{mL}, 62,5 \mu \mathrm{g} / \mathrm{mL}, 31,25$ $\mu \mathrm{g} / \mathrm{mL}, 15,625 \mu \mathrm{g} / \mathrm{mL}, 7,81 \mu \mathrm{g} / \mathrm{mL}, 3,90 \mu \mathrm{g} / \mathrm{mL}, 1,95$ $\mu \mathrm{g} / \mathrm{mL}, 0,97 \mu \mathrm{g} / \mathrm{mL}, 0,488 \mu \mathrm{g} / \mathrm{mL}, 0,244 \mu \mathrm{g} / \mathrm{mL}, 0,122$ $\mu \mathrm{g} / \mathrm{mL}, 0,061 \mu \mathrm{g} / \mathrm{mL}$.

Kultur hasil inisiasi dihomogenkan. Kontrol terdiri dari sel, medium IMDM, dan larutan dapar natrium fosfat $5 \mathrm{mM} \mathrm{pH}=7,2$. Blanko terdiri dari medium IMDM, larutan dapar natrium fosfat $5 \mathrm{mM} \mathrm{pH}=7,2$ dan variasi konsentrasi sampel enzim L-Asparaginase. Perlakuan untuk uji sitotoksisitas terdiri dari sel, medium IMDM, larutan dapar natrium fosfat $5 \mathrm{mM} \mathrm{pH}=7,2$ dan variasi konsentrasi sampel enzim L-Asparaginase. Sampel yang diuji adalah variasi konsentrasi sampel enzim LAsparaginase dengan aktivitas spesifik tertinggi.

\section{Penghitungan Persen Kematian Sel Menggunakan} Metode MTT

Larutan MTT dimasukkan dalam sumuran. Sel yang hidup akan membentuk kristal formazan berwarna ungu yang intensitasnya dapat diukur dengan ELISA Reader. Absorbansi yang terbaca sebanding dengan jumlah sel hidup.

\section{Analisis Hasil}

Sitotoksisitas variasi konsentrasi sampel enzim LAsparaginase dianalisa dengan menghitung persentase kematian sel yang diperoleh dari perhitungan menggunakan rumus Abbot [8]:

$$
\text { Persen kematian }=\frac{A-B}{A} \times 100 \%
$$

Keterangan:

A = Nilai rata-rata absorbansi dari beberapa kontrol

B = Nilai rata-rata absorbansi dari beberapa perlakuan

Efek toksisitas dianalisis dari pengamatan dengan persen kematian. Dengan mengetahui kematian sel kanker, kemudian dicari angka probit melalui tabel dan dibuat persamaan garis:

$$
\mathrm{Y}=\mathrm{Bx}+\mathrm{A}
$$

di mana: $\mathrm{Y}=$ Angka probit dan $\mathrm{X}=\log$ konsentrasi

Dari persamaan tersebut kemudian dihitung $\mathrm{LC}_{50}$ dengan memasukkan nilai probit (50\% kematian) [8].

\section{Hasil dan Pembahasan}

Isolasi dan Pemurnian Enzim L-Asparaginase dari Rimpang Temulawak (Curcuma xanthorrhiza Robx.)

Enzim L-Asparaginase dapat diperoleh dari rimpang temulawak (Curcuma xanthorrhiza Robx.) dengan mengeluarkan enzim tersebut dari jaringan secara mekanik, yaitu dengan diblender dan penambahan bufer Tris-hidroksimetil-aminometan. Proses pemblenderan menghasilkan campuran coklat yang terdiri dari komponen sel, protein dan non-protein dari temulawak. Pemisahan protein dari komponen non-protein dan sel dilakukan dengan penyaringan dan sentrifugasi pada filtrat. Sentrifugasi pada kecepatan yang sama, yaitu 
pada 3400 rpm selama 10 menit diperoleh endapan yang berwarna coklat yang merupakan komponenkomponen sel dari temulawak dan filtrat sebanyak 900 $\mathrm{mL}$ berwarna merah kekuningan yang merupakan enzim kasar (crude enzyme). Kemudian pengendapan protein menggunakan fraksinasi diikuti dengan sentrifugasi untuk memisahkan endapan dan supernatan. Endapan yang diperoleh merupakan protein enzim yang berwarna coklat dan masih mengandung amonium sulfat, maka dilakukan pemurnian lebih lanjut untuk memisahkan amonium sulfat dengan cara dialisis menggunakan membran selofan [9]. Hasil penelitian menunjukkan bahwa, penggantian bufer di luar membran dilakukan sebanyak enam kali, dengan volume setiap penggantian adalah $2000 \mathrm{~mL}$. Apabila tidak terbentuk endapan putih diperoleh enzim yang telah terbebas dari amonium sulfat, kemudian selanjutnya dilakukan uji unit aktivitas enzim dengan metode Nessler dan pengukuran kadar protein dengan metode lowry.

\section{Penentuan Unit Aktivitas dan Aktivitas Spesifik Enzim L-Asparaginase}

Penentuan aktivitas enzim L-Asparaginase dilakukan dengan mereaksikan enzim tersebut menggunakan substrat yang sesuai. Substrat yang digunakan pada reaksi enzimatis ini adalah Lasparagin. Penentuan aktivitas enzim L-Asparaginase dalam rimpang temulawak dilakukan melalui identifikasi amonia yang terbentuk dari proses penguraian tersebut dapat dianalisis dengan pereaksi Nessler.

Nilai aktivitas spesifik ini dapat digunakan sebagai ukuran besarnya kemurnian enzim hasil isolasi [5]. Kadar protein dapat ditentukan dengan metode Lowry. Penentuan aktivitas dan aktivitas spesifik terhadap enzim L-Asparaginase dari rimpang temulawak dilakukan pada EK, F1, F2, F3, F4, dan F5 yang diperoleh. Hasil penentuan aktivitas enzim spesifik disajikan pada tabel 1:

Tabel 1. Tabel penentuan aktivitas enzim spesifik LAsparaginase

\begin{tabular}{ccccc}
\hline Fraksi & $\begin{array}{c}\text { Aktivitas } \\
\text { Enzim } \\
(\text { Unit/mL) }\end{array}$ & $\begin{array}{c}\text { Kadar } \\
\text { Protein } \\
(\mathrm{mg} / \mathrm{mL})\end{array}$ & $\begin{array}{c}\text { Aktivitas } \\
\text { Spesifik } \\
\text { (Unit/mg } \\
\text { protein) }\end{array}$ & $\begin{array}{c}\text { Tingkat } \\
\text { Kemurnian }\end{array}$ \\
\hline EK & 393,345 & 13,653 & 28,809 & 1,000 \\
$\mathrm{~F}_{1}$ & 360,071 & 10,020 & 35,935 & 1,247 \\
$\mathrm{~F}_{2}$ & 407,605 & 8,886 & 45,867 & 1,592 \\
$\mathrm{~F}_{3}$ & 433,749 & 7,720 & 56,185 & 1,950 \\
$\mathrm{~F}_{4}$ & 480,095 & 6,220 & 77,185 & 2,679 \\
$\mathrm{~F}_{5}$ & 327,985 & 5,486 & 59,778 & 2,074 \\
\hline
\end{tabular}

Pada tabel 1 dapat diketahui bahwa aktivitas spesifik terendah diperoleh pada $\mathrm{F}_{1}$ dan aktivitas spesifik tertinggi diperoleh pada $\mathrm{F}_{4}(60-80 \%)$ yaitu 77,109 Unit/mg protein dengan tingkat kemurnian yang tertinggi pula dibanding ekstrak kasar dan di antara fraksi-fraksi lainnya. Oleh karena itu, dapat disimpulkan bahwa enzim L-Asparaginase sebagian besar terdapat pada $\mathrm{F}_{4}$. Pada penelitian sebelumnya [7] diperoleh aktivitas enzim spesifik pada kondisi optimum sebesar 75,091 Unit/mg protein. Perbedaan nilai aktivitas enzim spesifik yang diperoleh disebabkan perbedaan sumber temulawak dan kondisi temulawak yang digunakan dalam penelitian.

\section{Pengujian Enzim L-Asparaginase Aktivitas Tertinggi (Fraksi Empat) Pada Sel Kanker Leukemia(K562) Menggunakan Metode MTT}

Enzim dengan nilai aktivitas spesifik tertinggi (F4: 77,18 unit/mg) selanjutnya diujikan terhadap sel kanker leukemia tipe K562. Enzim yang diujikan terhadap sel leukemia tipe K562 dikeringkan dengan menggunakan freeze dryer. Freeze dryer adalah alat untuk proses liofilisasi, sehingga diperoleh enzim berupa serbuk kristal berwarna cokelat.

Enzim yang telah dikeringkan tersebut diuji pada sel kanker leukemia dengan menggunakan metode MTT, yang mana pembacaan dilakukan dengan ELISA Reader. Prinsip kerja dari instrumen ini hampir sama dengan spektrofotometer pada umumnya, yaitu interaksi (berupa absorbsi atau penyerapan) antara materi dengan energi yang berupa cahaya. Metode MTT adalah suatu tes laboratorium dan suatu metode standar kolorimetri (suatu metode yang mengukur perubahan warna) untuk mengukur pertumbuhan sel.

Pada proses uji sitotoksik larutan uji berupa enzim L-Asparaginase dibuat dalam 15 variasi konsentrasi. Sampel yang diuji adalah variasi konsentrasi sampel enzim L-Asparaginase dengan aktivitas spesifik tertinggi. Sel yang masih hidup masih aktif melakukan aktivitas metabolisme sehingga adanya MTT pada lingkungannya akan segera dipecah oleh enzim reduktase suksinat tetrazolium yang terdapat di dalam mitokondria sel tersebut membentuk kristal formazan berwarna ungu [10].

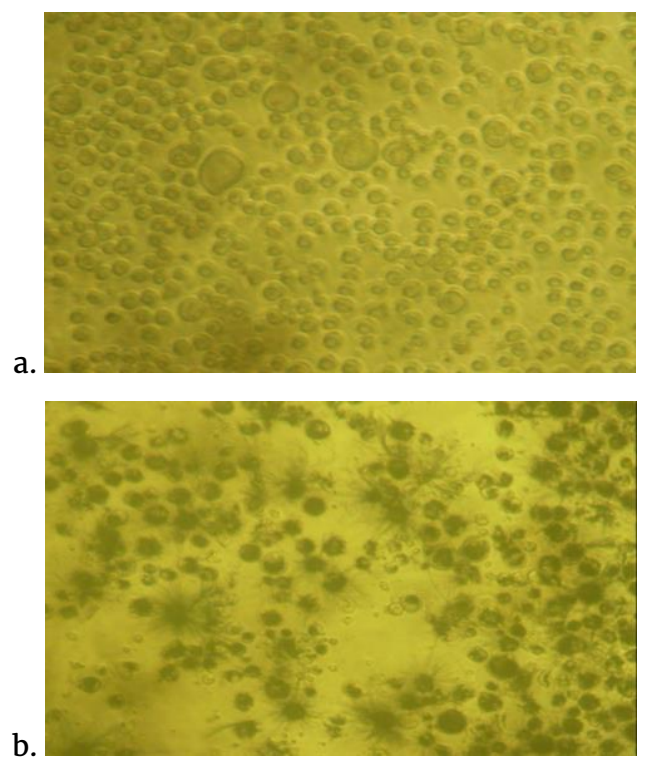

Gambar 2. (A) gambar sel leukemia sebelum ditambah dengan ekstrak enzim L-Asparaginase (B) gambar sel leukemia setelah ditambah dengan ekstrak enzim LAsparaginase dan penambahan MTT 
Pada gambar tersebut, sel-sel yang masih hidup berbentuk bulat utuh tidak mengalami perubahan bentuk, ukuran dan membentuk kristal formazan di sekitarnya, Sedangkan sel-sel yang mati ukurannya cenderung lebih kecil karena sebagian isi sel (sitoplasma) keluar, hal ini disebabkan susunan atau integritas membran sel tersebut telah rusak.

Hasil pembacaan absorbansi dengan Elisa Reader di plotkan dalam bentuk grafik . Data dan grafik hasil uji sitotoksisitas enzim L-Asparaginase fraksi ke-4 dari temulawak terhadap sel leukemia tipe K562 yang dinyatakan dalam persen kematian dapat dilihat pada gambar 3 di bawah ini

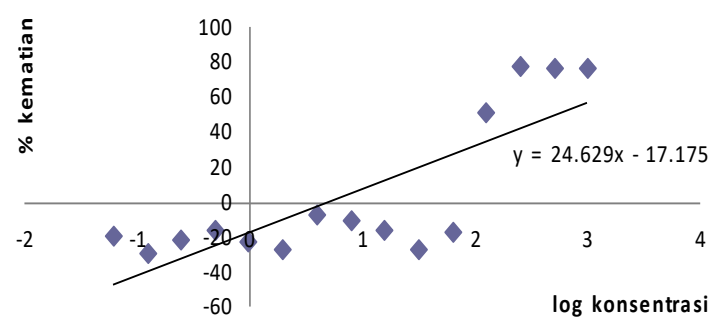

Gambar 3. Mortalitas sel leukemia hasil uji MTT

Pada gambar 3 diperoleh persamaan y = 24,629x17,175. Persamaan tersebut selanjutnya digunakan untuk menghitung nilai $\mathrm{LC}_{50}$ dengan memasukkan nilai 50 sebagai y sehingga didapatkan nilai $x$. Nilai $x$ menunjukan nilai log dari konsentrasi fraksi ke-4 enzim L-Asparaginase. Konsentrasi fraksi ke-4 enzim LAsparaginase adalah antilog 2,728 yaitu 534,89 $\mu \mathrm{g} / \mathrm{mL}$. Hal ini berarti bahwa kematian dari sel kanker leukemia K562 mencapai 50\% dengan adanya penambahan enzim L-Asparaginase dengan konsentrasi 534,89 $\mu \mathrm{g} / \mathrm{mL}$.

Enzim L-Asparaginase mampu menghambat serta mematikan sel kanker dapat di lihat dari berkurangnya sel kanker setelah penambahan enzim L-Asparaginase, namun menurut NCI (National Cancer Institute) jika suatu uji sitotoksik suatu senyawa menghasilkan harga $\mathrm{LC}_{50} \leq$ $20 \mathrm{\mu g} / \mathrm{mL}$ maka senyawa tersebut dinyatakan memiliki potensi untuk dikembangkan sebagai senyawa antikanker [11]. Karena nilai $\mathrm{LC}_{50}$ enzim L-Asparaginase fraksi ke-4 dari temulawak yang diuji lebih dari 20 $\mu \mathrm{g} / \mathrm{mL}$, maka senyawa bioaktif tersebut kurang potensial untuk digunakan sebagai antikanker. khususnya terhadap sel leukemia K562.

\section{Kesimpulan}

Temulawak mengandung enzim L-Asparaginase dan memiliki aktivitas spesifik tertinggi pada fraksi ke 4 (60 - 80\%) dengan aktivitas spesifik 77,18 unit/mg protein pada kondisi optimum. Enzim L-Asparaginase fraksi ke4 rimpang temulawak telah diujikan pada sel kanker leukimia tipe K562. Fraksi tersebut kurang potensial sebagai senyawa antikanker.

\section{Daftar Pustaka}

[1] Sulistia G. Ganiswara, Farmakologi dan Terapi, 4 ed., Bagian Farmakologi Fakultas Kedokteran Universitas Indonesia, Jakarta, 1995.
[2] Maksum Radji, Atiek Sumiati, Nuning Indani, Uji Mutagenisitas dan Anti Kanker Ekstrak Aseton dan n-Heksana dari Kulit Batang Sesoot (Garcinia picrorrhiza Miq.), Majalah Ilmu Kefarmasian, 1, 2, (2004) 69-78

[3] Wesley A. Volk, Margaret F. Wheeler, Mikrobiologi Dasar, Markham, Erlangga, Jakarta, 1993.

[4] Abraham White, Philip Handler, Emil L. Smith, Principles of Biochemistry, 6 ed., Mcgraw-Hill, 1978.

[5] Albert L Lehninger, Dasar-Dasar Biokimia, M. Thenawidjaja, Erlangga, Jakarta, 1990.

[6] P. Konečná, B. Klejdus, H. Hrstková, Monitoring The Asparaginase Activity and Asparagine Levels in Children with Acute Lymphoblastic Leukaemia Treated with Different Asparaginase Preparations, Scripta Medica (BRNO), 77, 2, (2004) 55-62

[7] Didik Adika Haninda, Isolasi dan Karakterisasi Enzim L-Asparaginase dari Rimpang Temulawak (Curcuma xanthorrhiza Roxb.) Dalam Sediaan Utuh dan Serbuk, Skripsi, ^Jurusan Kimia, Universitas Diponegoro, Semarang

[8] B. N. Meyer, N. R. Ferrigni, J. E. Putnam, L. B. Jacobsen, D. E. Nichols, J. L. McLaughlin, Brine Shrimp: A Convenient General Bioassay for Active Plant Constituents, Planta Med, 45, 05, (1982) 31-34 http://dx.doi.org/10.1055/s-2007-971236

[9] Felix Franks, Characterization of Proteins, Humana Press, 1988.

[10] R. Ian Freshney, Culture of Animal Cells: A Manual of Basic Technique and Specialized Aplication, Lissing, New York, 1986.

[11] M. Suffness, J. M. Pezzuto, Assay Related to Cancer Drug Discovery, in: K. Hostettman (Ed.) Methods in Plant Biochemistry: Assay for Bioactivity, Academic Press, London, 2009, pp. 71-133. 